\title{
Dysferlinopathy Promotes an Intramuscle Expansion of Macrophages with a Cyto-Destructive Phenotype
}

\author{
Jea-Hyun Baek, ${ }^{*}$ Gina M. Many, ${ }^{*}$ Frances J. Evesson, ${ }^{\dagger}$ and Vicki R. Kelley*
}

From the Laboratory of Molecular Autoimmune Disease, * Renal Division, Department of Medicine, Brigham and Women's Hospital, Boston; and the Department of Cell Biology, ${ }^{\dagger}$ Harvard Medical School and Program in Cellular and Molecular Medicine, Boston Children's Hospital, Boston, Massachusetts

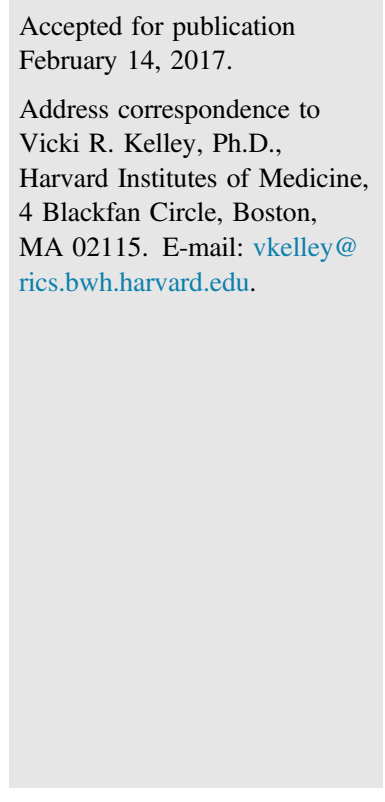

Accepted for publication

February 14, 2017.

Address correspondence to Vicki R. Kelley, Ph.D. Harvard Institutes of Medicine, 4 Blackfan Circle, Boston, MA 02115. E-mail: vkelley@ rics.bwh.harvard.edu.

\begin{abstract}
Dysferlinopathies are a group of muscular dystrophies resulting from a genetic deficiency in Dysf. Macrophages, highly plastic cells that mediate tissue repair and destruction, are prominent within dystrophic skeletal muscles of dysferlinopathy patients. We hypothesized that Dysf-deficient muscle promotes recruitment, proliferation, and skewing of macrophages toward a cyto-destructive phenotype in dysferlinopathy. To track macrophage dynamics in dysferlinopathy, we adoptively transferred enhanced green fluorescent protein-labeled monocytes into Dysf-deficient BLA/J mice with age-related (2 to 10 months) muscle disease and Dysf-intact (C57BL/6 [B6]) mice. We detected an age- and disease-related increase in monocyte recruitment into Dysf-deficient muscles. Moreover, macrophages recruited into muscle proliferated locally and were skewed toward a cyto-destructive phenotype. By comparing Dysf-deficient and -intact monocytes, our data showed that Dysf in muscle, but not in macrophages, mediate intramuscle macrophage recruitment and proliferation. To further elucidate macrophage mechanisms related to dysferlinopathy, we investigated in vitro macrophage-myogenic cell interactions and found that Dysf-deficient muscle i) promotes macrophage proliferation, ii) skews macrophages toward a cyto-destructive phenotype, and iii) is more vulnerable to macrophage-mediated apoptosis. Taken together, our data suggest that the loss of Dysf expression in muscle, not macrophages, promotes the intramuscle expansion of cyto-destructive macrophages likely to contribute to dysferlinopathy. Identifying pathways within the Dysf-deficient muscle milieu that regulate cytodestructive macrophages will potentially uncover therapeutic strategies for dysferlinopathies. (Am J Pathol 2017, 187: 1245-1257; http://dx.doi.org/10.1016/j.ajpath.2017.02.011)
\end{abstract}

Dysferlinopathies are a group of autosomal recessive neuromuscular diseases caused by a genetic deficiency in dysferlin (Dysf), a protein involved in muscle repair. ${ }^{1,2}$ The absence of Dysf triggers progressive skeletal muscle wasting that often begins suddenly in a patient's late teens or early adulthood, and within a decade the patient has limited use of his or her limbs. ${ }^{1}$ Macrophage-rich unrelenting inflammation in muscles from patients and mice is characteristic of this form of muscular dystrophy. ${ }^{3}$ The intramuscle accumulation of macrophages is notably more abundant in dysferlinopathy than in other inflammatory muscle diseases. ${ }^{4}$ Despite the prominence of macrophages in dysferlinopathy, the role of these myeloid cells remains a mystery. Because there is no effective treatment for dysferlinopathy, clarifying the mechanisms responsible for intramuscle macrophage expansion and the impact of macrophages in this illness will undoubtedly uncover novel therapeutic targets.

The burning question is whether macrophages in Dysfdeficient hosts are programed to repair or destroy muscle. To probe for the role of intramuscle macrophages in nonresolving inflammation leading to muscular dystrophy, it is essential to understand normal muscle repair. Fundamentally, macrophage-mediated inflammation is a necessary

\footnotetext{
Supported by Jain Foundation (V.R.K.) and Deutsche Forschungsgemeinschaft fellowship BA 4875/1-1 (J.-H.B.).

Disclosures: V.R.K. owns stock in Biogen.
} 
antecedent to healing because it sets the stage for repair. Within this context, it is important to appreciate that macrophages are highly plastic myeloid cells with extremely diverse functions. For simplicity, macrophages are broadly divided into two subsets, classically activated (M1) cytodestructive and alternatively activated (M2) tissuereparative leukocytes. ${ }^{5}$ Within this framework macrophages are further subdivided according to polarization, gene expression, and function. ${ }^{6}$ With this stratification in mind, injured muscle initially recruits nondividing, proinflammatory monocytes to the damaged site. ${ }^{7}$ Once within the inflamed muscle, macrophages shift from a cyto-destructive M1 to a tissue-reparative M2, a shift that may result from macrophage phagocytosis of debris. ${ }^{8-11}$ Tissue-reparative intramuscle macrophages then proliferate and in turn stimulate myogenesis and fiber growth that lead to muscle repair. ${ }^{7}$ In support of this concept, even partial macrophage depletion in the inflamed muscle impedes regeneration. ${ }^{12}$ Taken together, the shift from an M1 cyto-destructive to a dominant M2 tissue-reparative macrophage population is central to muscle repair.

However, macrophage-rich Dysf-deficient muscles do not heal, but rather succumb to progressive muscular dystrophy. Is failed muscle repair in Dysf-deficient hosts dependent on the absence of this gene in muscles and/or in macrophages? Ample evidence indicates that inflammation is initiated in the Dysf-deficient muscle. ${ }^{13,14}$ This concept is based on the central role of Dysf, a calcium binding membrane-associated protein, in critical membrane functions, including repair. ${ }^{3}$ Convincingly, the pathologic process of Dysf-deficient (A/J) mice is completely rescued by overexpressing Dysf in skeletal muscle (Dysf transgenic mice), suggesting that the phenotype of muscular dystrophy is initiated in muscle and not by other cell types. ${ }^{15}$ However, once initiated, we hypothesize that macrophages contribute to progressive muscle destruction. To test this hypothesis, we investigated whether i) the Dysf-deficient inflamed muscle microenvironment recruits macrophages, skews these myeloid cells toward an M1 macrophage cyto-destructive, not M2 macrophage tissuereparative, phenotype, and fosters proliferation of cytodestructive macrophages; ii) the absence of Dysf in muscle, but not in macrophages, mediates recruitment into the inflamed muscle and promotes proliferation; and iii) Dysfdeficient myogenic cells in comparison with Dysf-intact cells are more vulnerable to M1 macrophage-mediated muscle destruction (apoptosis/necrosis) and skew macrophages to a M1 phenotype.

Because the human and mouse Dysf genes share $>90 \%$ amino acid sequence homology, ${ }^{16}$ we used the wellcharacterized Dysf-deficient mutant mice that develop progressive dysferlinopathy ${ }^{17}$ to probe for macrophage-muscle interactions instrumental in this disease. We tracked macrophage phenotypes and actions within inflamed muscle using genetic fate mapping. Coupled with in vitro strategies we clarified macrophage-muscle interactions central to dysferlinopathy. Combined, our in vivo and in vitro data suggest that Dysf deficiency in muscle, not macrophages, drives macrophage recruitment and skewing toward a cytodestructive phenotype, which may, in turn, lead to muscle destruction. Thereby, our findings offer the potential of identifying novel therapeutic targets for dysferlinopathy.

\section{Materials and Methods}

Mice

The transgenic strain (Tgfms-EGFP), expressing enhanced green fluorescent protein (eGFP) under control of the colony-stimulating factor 1 receptor $(c-f m s)$ promoter and first intron (referred to as MacGreen mice), were provided by Dr. David Hume (Roslin Institute, Edinburgh, Scotland). These mice were backcrossed into the B6 background. ${ }^{18,19}$ Dysf-deficient B6.A-Dysf ${ }^{\text {prmd } / G e n e J ~(B L A / J), ~ M a c G r e e n ~}$ reporter mice on the BLA/J background B6.A-Dysf $\mathrm{fr}^{\text {prmd/ }}$ GeneJxB6N.Cg-Tg (Csf-1r-EGFP)1Hume/J (MacGreen: BLA/J), and C57B1/6 (B6) background were obtained from The Jackson Laboratory (Bar Harbor, ME). Mice were housed at Harvard Medical School. Use of mice in this study was reviewed and approved by the Standing Committee on Animals in the Harvard Medical School in adherence to standards set in the Guide for the Care and Use of Laboratory Animals. ${ }^{20}$

\section{Muscle Histopathologic Analysis}

Muscle tissues for histopathologic analysis were fixed in $10 \%$ neutral buffered formalin, embedded in paraffin, sectioned $(5 \mu \mathrm{m})$, and stained with hematoxylin and eosin. Muscle disease was assessed according to the following scoring system: $0=$ normal muscle with peripheral nuclei, tightly and orderly aligned fibers of relatively the same size; $1=$ signs of muscle damage, including necrosis, cell infiltration, regenerating fibers, fiber size variation, no or little fat/ adipose tissue deposition; $2=$ same signs as score 1 with increased fiber size variation and moderate fat deposition $(\leq 50 \%) ; 3=$ extensive degree for all signs of muscle injury and extensive adipose tissue deposition $(\geq 50 \%)$.

\section{Immunostaining}

Muscle cryosections ( $5 \mu \mathrm{m})$ were stained for the presence of macrophages, using anti-mouse anti-F4/80 antibody (Ab; BM-8; Invitrogen, Carlsbad, CA) and anti-mouse CD68 Ab (FA-11; Bio-Rad AbD Serotec, Raleigh, NC), as previously detailed. ${ }^{18}$ To combine immunostaining with histopathologic analysis, we counterstained with hematoxylin and eosin. To determine the number of proliferating macrophages, we stained cryosections of muscle with anti-mouse CD68 Ab, and anti-mouse Ki-67 Ab (SP6; Vector Laboratories, Burlingame, CA), followed by fluorescein isothiocyanate (FITC)-conjugated goat anti-rat IgG Ab (Invitrogen) and cyanine (Cy)3-conjugated goat anti-rabbit $\operatorname{IgG} \mathrm{Ab}$ 
(Invitrogen). We enumerated the number of $\mathrm{CD} 68^{+} / \mathrm{Ki}-67^{+}$ cells per field in the entire cross section.

\section{Flow Cytometry}

Muscle tissues were minced and dissociated into a single-cell suspension using collagenase type $4(1 \mathrm{mg} / \mathrm{mL}$; Worthington, Lakewood, NJ). We stained single-cell suspensions from muscles or blood cells as described previously. ${ }^{21}$ To detect intracellular antigens, we stained the extracellular antigens for 20 minutes at $4{ }^{\circ} \mathrm{C}$. Then, we fixed cells with $4 \%$ paraformaldehyde at room temperature for 20 minutes $^{22}$ and washed once in permeabilization wash buffer (BioLegend, San Diego, CA). Subsequently, we incubated the cells with Abs for intracellular antigens in permeabilization wash buffer overnight at $4^{\circ} \mathrm{C}$. After washing, cells were counted and analyzed on BD LSR II (BD Biosciences, San Jose, CA) equipped with a high-throughput screening unit.

\section{Flow Cytometric Abs}

We used the following Abs from BioLegend for fluorescence-activated cell sorting analysis: FITC or Brilliant Violet 510-conjugated anti-mouse/human CD11b Ab (M1/70), Pacific Blue-conjugated anti-mouse CD45 Ab (30-F11), phycoerythrin (PE)/Cy7-conjugated anti-mouse IL-10 Ab (JES5-16E3), biotinylated or PE-conjugated anti-mouse Ly6C Ab (HK1.4), allophycocyanin/Cy7conjugated anti-mouse Ly6G Ab (1A8), allophycocyaninconjugated anti-mouse transforming growth factor (TGF)- $\beta 1$ Ab (TW7-16B4), peridinin chlorophyll protein/ Cy5.5-conjugated anti-mouse tumor necrosis factor (TNF)$\alpha$ Ab (MP6-XT22), and peridinin chlorophyll protein/ Cy5.5-conjugated streptavidin. In addition, we used FITCconjugated anti-nitric oxide synthase type II Ab (NOS-II; 6/iNOS/NOS Type II) from BD Biosciences, PE-conjugated anti-NOS-II Ab (CXNFT) from eBioscience (San Diego, $\mathrm{CA}$ ), and PE-conjugated anti-Arginase-1 polyclonal $\mathrm{AB}$ from R\&D Systems (Minneapolis, MN).

\section{BrdU Incorporation Assay}

Unless otherwise stated, we injected mice with bromodeoxyuridine (BrdU; 2 mg/mouse i.p.; Sigma-Aldrich, St. Louis, MO) 3 hours before sacrifice. BrdU ${ }^{+}$cells were analyzed by flow cytometry with an anti-BrdU Ab (Bu20a; BioLegend).

\section{Adoptive Transfer}

Bone marrow (BM) was isolated from MacGreen:BLA/J or MacGreen:B6 mice and adoptively transferred these $\mathrm{eGFP}^{+}$ cells $\left(1 \times 10^{8}\right.$, intravenously injected $)$ into BLA/J and B6 mice. Mice were sacrificed and muscle and blood samples were processed to detect eGFP ${ }^{+}$cells using flow cytometry as previously described. ${ }^{22}$

\section{Thioglycollate-Induced Peritonitis}

Peritonitis was induced using thioglycollate $(1.5 \mathrm{~mL}$ of $4 \%$ ) injected (i.p.) into BLA/J and B6 mice (11 weeks of age). At varying times after injection, peritoneal cells were harvested and analyzed by flow cytometry.

\section{Myogenic Cell-Mediated Macrophage Skewing}

Dysf-deficient (A/J) and wild-type (WT) myoblasts were a kind gift from Dr. Terence Partridge (Children's National Medical Center, Washington, DC). Cells were grown as previously described. ${ }^{23,24}$ On reaching confluence, myoblasts were induced to differentiate into myotubes (single to triple nucleated myocytes; referred to as myogenic cells) for 5 days with a media change at day 2 , in myotube differentiation media [Dulbecco's modified Eagle's medium (DMEM) supplemented with $2 \%$ horse serum]. Cell-free myogenic cell-conditioned medium was collected at day 5 for macrophage stimulation. WT $\mathrm{eGFP}^{+} \mathrm{BM}$ macrophages were generated from mouse BM as previously detailed. $^{21}$ Before stimulation, BM macrophages were plated overnight in L929 media. The next day, cells were primed overnight with $100 \mathrm{IU} / \mathrm{mL}$ interferon (IFN)- $\gamma$ in RPMI media containing 10\% fetal calf serum (Gibco, Carlsbad, CA). After priming, cells were washed and stimulated with myogenic cell-conditioned media supplemented with $5 \mu \mathrm{g} / \mathrm{mL}$ Brefeldin A (BioLegend). Control cells were treated with neat myotube differentiation media supplemented with $100 \mathrm{ng} / \mathrm{mL}$ lipopolysaccharide (LPS). After 3.5 hours of stimulation, cells were harvested using Cellstripper (CellGro, Manassas, VA). Extracellular (F4/80) and intracellular staining was performed as described above, with intracellular staining for 1 hour, before washing and fluorescence-activated cell sorting analysis.

\section{Macrophage-Mediated Myogenic Cell Apoptosis}

Dysf-deficient and WT myoblasts were induced to differentiate at approximately $70 \%$ confluence for 2 days. Subsequently, $3 \times 10^{5} \mathrm{WT} \mathrm{eGFP}^{+} \mathrm{BM}$ macrophages were added per well in myotube differentiation media. BM macrophages for co-culture experiments were stimulated for 45 minutes with $20 \mathrm{ng} / \mathrm{mL}$ TNF- $\alpha$ and $100 \mathrm{ng} / \mathrm{mL}$ LPS at $37^{\circ} \mathrm{C}$ in RPMI supplemented with $10 \%$ fetal calf serum (Gibco).

\section{Induction of Macrophage Proliferation by Myogenic Cell Supernatant Fluid}

Myogenic cells were stimulated with $25 \mathrm{ng} / \mathrm{mL}$ murine TNF- $\alpha$ (R\&D Systems) for 24 hours. Cells were washed three times with phosphate-buffered saline and further cultured in serum-free medium. After an additional 24 hours, cell supernatant fluid was collected and used to stimulate BM macrophages starved in DMEM without L929 for 2 hours. These BM macrophages were incubated with 
myogenic cell supernatant fluids for 24 hours. Macrophage proliferation was analyzed using $1 \mathrm{mmol} / \mathrm{L} \mathrm{BrdU}$ incorporation for 2 hours and flow cytometric analysis.

\section{Statistical Analysis}

Data represent the means \pm SEM prepared using GraphPad Prism software version 5.0 (GraphPad Software, La Jolla, CA). Normality was tested using the Shapiro-Wilk test. Data were analyzed using the nonparametric $U$-test to evaluate $P$ values. $P<0.05$ was considered significant.

\section{Results}

Tissue-Resident Macrophages Progressively

Accumulate in Proportion to the Severity of Dysferlinopathy in BLA/J Mice

The severity of the pathologic disorder is highly variable in patients with dysferlinopathy. ${ }^{17,25}$ In general, muscles in the limb-girdle region are most susceptible to this illness. ${ }^{1,26}$ With the use of BLA/J mice $[\mathrm{A} / \mathrm{J}$ mice spontaneously deficient in Dysf backcrossed into the C57BL/6 (B6) background], ${ }^{25}$ we systematically analyzed the magnitude of the disease in different muscle groups: the psoas, gluteus, and tibialis anterior (TA). Muscle pathologic characteristics consisted of increased inflammatory infiltrates surrounding necrotic myofibers and adipocyte infiltration with age (Supplemental Figure S1A). Consistent with prior reports, ${ }^{17,25}$ disease was more prominent in the psoas muscle than in the gluteus muscle, whereas the TA muscle remained largely unaffected, even at 12 months of age (Supplemental Figure S1B). Therefore, to test our hypothesis, we used the gluteus and psoas muscles with advancing dysferlinopathy and the TA as an unaffected control.

To quantify the progressive rise in myeloid cells in muscle during dysferlinopathy, we probed for macrophages and neutrophils in the gluteus, psoas, and TA muscles during advancing disease (Supplemental Figure S2A). Macrophages $\left(\mathrm{CD} 45^{+} \mathrm{CD} 11 \mathrm{~b}^{+} \mathrm{Ly} 6 \mathrm{G}^{-} \mathrm{F} 4 / 80^{+}\right)$were the predominant leukocyte population and increased with advancing stages of dysferlinopathy (Supplemental Figure S2A and Supplemental Figure S3). Macrophages were more abundant in the psoas than gluteus muscles ( 8 months of age); however, macrophages continued to rise in the gluteus but leveled off in the psoas (12 to 14 months of age) owing to massive tissue destruction (Supplemental Figure S3). By comparison, macrophages rose at a much slower rate in the TA muscle (Supplemental Figure S3). To pinpoint the location of intramuscle macrophage-advancing dysferlinopathy, we probed for macrophage expression in situ. The majority (approximately 85\%) of macrophages $\left(\mathrm{F} 4 / 80^{+}\right)$accumulated adjacent to necrotic muscle fibers in the Dysf-deficient gluteus muscle (BLA/J mice 14 months of age) (Supplemental Figure S2B). Thus, macrophages accumulated adjacent to necrotic myofibers in BLA/J mice with advancing dysferlinopathy.

To establish the origin of macrophages in BLA/J muscle, we probed for Ly6C expression, a surface marker expressed by blood circulating inflammatory monocytes recruited into inflamed tissues. ${ }^{7}$ In contrast, tissue-resident macrophages are $\mathrm{Ly} 6 \mathrm{C}^{-}$. We found that most macrophages in inflamed Dysf-deficient gluteus muscle were $\mathrm{Ly}^{-} \mathrm{C}^{-}$and these macrophages increased with advancing disease (Supplemental Figure S2A). These results suggested that either the bulk of intramuscle macrophages arise from local proliferation of tissue-resident macrophages or recruited $\mathrm{Ly} 6 \mathrm{C}^{+}$monocytes were converted into Ly6 $\mathrm{C}^{-}$macrophages within the Dysfdeficient inflamed microenvironment. ${ }^{7}$ In contrast, neutrophils $\left(\mathrm{CD} 45^{+} \mathrm{CD} 11 \mathrm{~b}^{+} \mathrm{Ly} 6 \mathrm{G}^{+}\right)$, acute responders to muscle injury, were barely detectable at any age (Supplemental Figure S2A). These results indicated that $\mathrm{Ly} 6 \mathrm{C}^{-}$macrophages comprise the predominant myeloid population that increase with advancing disease in inflamed BLA/J muscle.

\section{Circulating Monocytes Are Actively Recruited into Dysf-Deficient Muscle with Advancing Disease}

To determine whether recruited BM monocytes give rise to macrophages in Dysf-deficient muscles, we used a genetic fate mapping approach. We adoptively transferred BM cells from MacGreen:B6 (eGFP reporter for $c$-Fms expressed by macrophages $)^{27}$ into BLA/J mice. We analyzed adoptively transferred $\mathrm{eGFP}^{+} \mathrm{BM}$-derived macrophages (BM macrophages) recruited into the psoas, gluteus, and TA muscles at time-related stages of dysferlinopathy: early ( 2 months of age), mild (7 months of age), and advanced (10 months of age) (Figure 1A). To identify macrophages that are recruited into muscle, we included F4/80 as a marker. Note, F4/80 was expressed at low levels in circulating monocytes but increased after entry into inflamed tissue (within 3 hours) (Supplemental Figure S4A). Monocyte migration increased in the psoas and gluteus muscles with advancing disease $(10>7>2$ months of age $)$ in BLA/J mice. We detected the largest number of $\mathrm{eGFP}^{+}$donor-derived macrophages in the muscle with the most severe disease, the psoas. By comparison, monocyte migration into the TA, a muscle that remained nearly unaffected, barely rose above baseline (B6 mice at 2 months of age) (Figure 1A). These results indicated that monocyte recruitment into inflamed Dysfdeficient muscle increases with advancing disease.

\section{Dysf Expression in Monocytes Does Not Alter Recruitment into Dysf-Deficient Muscle}

Because Dysf is expressed in monocytes, ${ }^{28,29}$ we investigated whether recruitment into BLA/J inflamed muscles depends on the absence of Dysf in macrophages. We compared the number of intramuscle donor MacGreen: BLA/J (eGFP ${ }^{+}$Dysf-deficient) and MacGreen:B6 (eGFP ${ }^{+}$ Dysf-intact) macrophages after adoptive transfer 

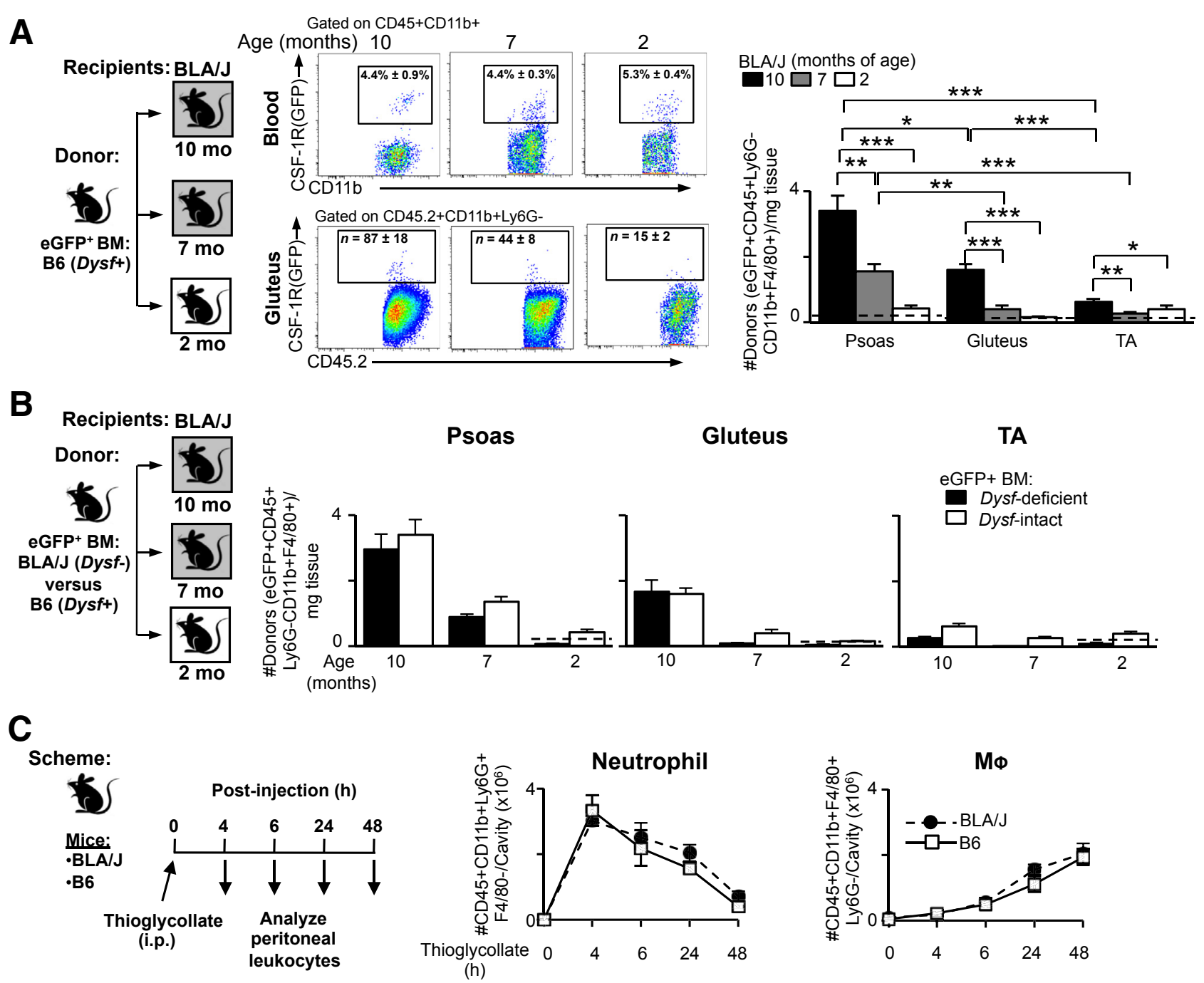

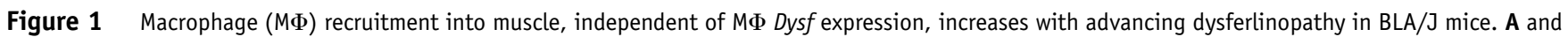
B: We injected enhanced green fluorescent tibialis anterior protein (eGFP) ${ }^{+}$Dysf-intact (A) or Dysf-deficient (B) bone marrow (BM) $\left(1 \times 10^{8}\right)$ into BLA/J $(2,7$, and 10 months of age) and B6 mice (2 months of age) 3 hours before sacrifice. $M \Phi$ recruitment was analyzed in psoas, gluteus, and tibialis anterior (TA muscles) by flow cytometry. Dashed lines indicate B6 muscles (2 months of age). C: Peritonitis was induced in BLA/J and B6 mice (2 months of age) by injecting (i.p.) thioglycollate. Peritoneal leukocytes were quantified at varying times after injection by flow cytometry. Statistics analyzed with $U$-test. Data are expressed as means \pm SEM. $n=6$ to 7 (A and $\mathbf{B}) ; n=5$ B6 mice at 2 months of age $(\mathbf{A}$ and $\mathbf{B}) ; n=5$ (C). ${ }^{*} P<0.05,{ }^{*} P<0.01$, and ${ }^{* * *} P<0.001$. CSF-1R, colony-stimulating factor 1 receptor.

(Figure 1B). The percentage of $\mathrm{eGFP}^{+}$monocytes (approximately $8 \%$ ) in the $\mathrm{BM}$ did not differ between MacGreen:BLA/J and MacGreen:B6 mice. Therefore, we were confident that we transferred equal numbers of MacGreen:BLA/J and MacGreen:B6 monocytes (Supplemental Figure S5). We found similar numbers of $\mathrm{eGFP}^{+}$macrophages in the Dysf-deficient inflamed muscle, regardless of macrophage Dysf expression (Figure 1B). To broaden this concept, we tested the hypothesis that macrophage recruitment is independent of Dysf expression in sites other than muscle using a thioglycollate-induced peritonitis approach (Figure 1C). Consistent with our findings in Dysf-deficient muscle, monocyte recruitment into the inflamed peritoneum was similar in monocytes with and without $D y s f$ expression (Figure 1C). Thus, the absence of Dysf in monocytes does not regulate monocyte recruitment into inflamed muscles. However, because we used MacGreen:BLA/J mice at 2 to 3 months of age for donors and in the thioglycollate experiment, we cannot discount that age-induced alterations in monocytes in dysferlin-deficient mice contribute to recruitment.

Macrophages Proliferate Adjacent to Necrotic Muscle Fibers and Thereby May Contribute to Macrophage Accumulation in Dysf-Deficient Muscle

Our data indicated that adoptively transferred BM cells are recruited into the Dysf-deficient inflamed muscle. However, we found $\mathrm{Ly} 6 \mathrm{C}^{-}$, not $\mathrm{Ly} 6 \mathrm{C}^{+}$, a marker for migratory inflammatory monocytes, in inflamed muscle that rose with 

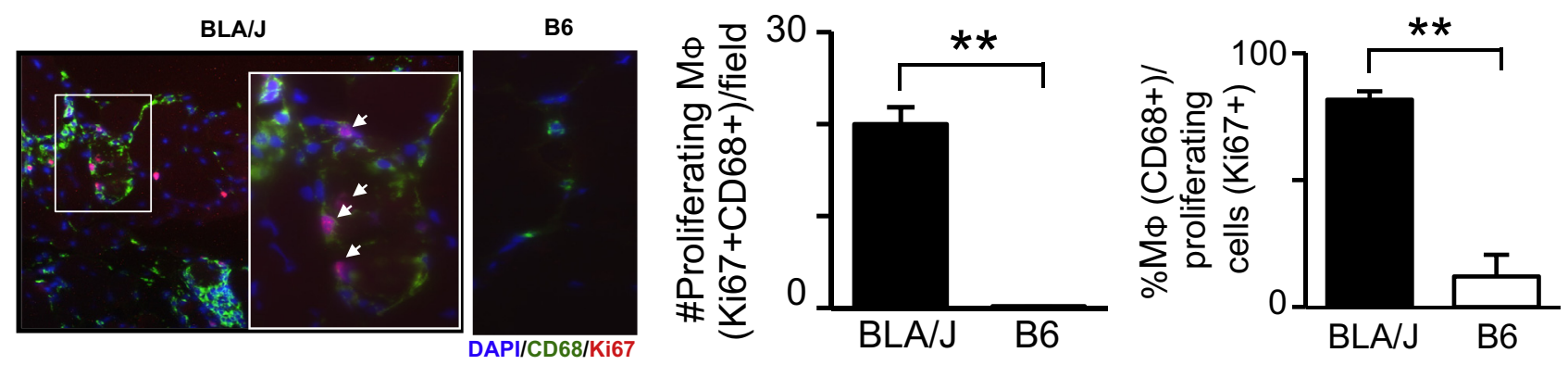

Figure 2 Macrophage (M $\Phi$ ) proliferate in BLA/J muscles with dysferlinopathy. Cryosections from gluteus muscles of BLA/J and B6 mice (14 months of age) stained with DAPI (blue), anti-CD68 (green), and anti-Ki67 (red) antibody (Ab). The boxed area is shown at higher magnification in the inset. Arrows indicate proliferating $\mathrm{M} \Phi\left(\mathrm{Ki}-67^{+} \mathrm{CD}^{+} 8^{+}\right)$. Graphs indicate proliferating $\mathrm{M} \Phi\left(\mathrm{Ki}-67^{+} \mathrm{CD}^{+} 8^{+}\right) /$field in section of entire gluteus and $\mathrm{M} \Phi(\%)$ among proliferating cells $\left(\mathrm{Ki}-67^{+}\right)$. Statistics analyzed with $U$-test. Data are expressed as means \pm SEM. $n=7 .{ }^{*} P<0.01$. Original magnification: $\times 10(\mathrm{BLA} / \mathrm{J}) ; \times 40($ inset $) ; \times 40$ (B6).

advancing dysferlinopathy. Therefore, we hypothesized that the Dysf-deficient muscle microenvironment promotes the expansion of macrophages. To test this hypothesis we probed for macrophages dividing within Dysf-deficient inflamed BLA/J muscles. With the use of immunostaining, we detected proliferating macrophages $\left(\mathrm{Ki}-67^{+} \mathrm{CD} 68^{+}\right)$in BLA/J muscles with dysferlinopathy (Figure 2). Moreover, most proliferating cells were macrophages (Figure 2). By comparison, we detected few proliferating macrophages in healthy muscle (Figure 2). The bulk of macrophages in inflamed BLA/J muscle were adjacent to necrotic muscle fibers (Supplemental Figure S2C). Therefore, our data suggested that macrophages adjacent to necrotic muscle fibers are proliferating.

\section{Monocytes Recruited into Dysf-Deficient Muscle Are Triggered to Proliferate}

To determine whether the monocytes recruited into the inflamed Dysf-deficient muscle are triggered to proliferate and thereby account for macrophage expansion, we adoptively transferred MacGreen BM cells (eGFP expression on macrophages) and analyzed macrophage proliferation in the psoas, gluteus, and TA muscles. We used BLA/J mice at 10 to 12 months of age with inflamed muscles as recipients (Figure 3A). Note, monocyte recruitment into BLA/J mice at 2 months of age with normal muscles was minimal (Figure 1A). We analyzed the number of macrophages after 3 hours and 5, 8, and 30 days after adoptive transfer. Because macrophages divide every 18 to 24 hours, ${ }^{30}$ the number of intramuscle $\mathrm{eGFP}^{+}$macrophages at 3 hours was due to recruitment, whereas $\mathrm{eGFP}^{+}$cells at later points represented macrophages that were recruited and locally multiplied. As expected the donor $\mathrm{eGFP}^{+}$monocytes in the blood were maximal at 3 hours after adoptive transfer and declined with time (Figure 3A). The number of eGFP ${ }^{+}$ donor-derived macrophages in BLA/J muscle (3 hours) increased dramatically by 5 days. As anticipated, eGFP ${ }^{+}$ cells accumulated more in the psoas muscle than the gluteus and the TA muscles, which was sparsely populated by
$\mathrm{eGFP}^{+}$cells. eGFP ${ }^{+}$macrophages began to decline by 8 days and were no longer detectable by 30 days (Figure $3 \mathrm{~A}$ ). These results suggested that in the long term there is a balance between macrophage proliferation and the disappearance of $\mathrm{eGFP}^{+}$macrophages related to cell death or migration from muscle into draining lymph nodes. ${ }^{31}$ Similarly, CD68 and Ki-67 costaining of cryosections from BLA/J muscles with dysferlinopathy showed that macrophages proliferate within inflamed muscles (Figure 2). Because we could not exclude the possibility that the increase of $\mathrm{eGFP}^{+}$macrophages in muscle, at least partly, resulted from continued recruitment from blood, we administered BrdU to BLA/J mice every 12 hours for 8 days after adoptive transfer. We found that BrdU was incorporated in $>93 \%$ of $\mathrm{eGFP}^{+}$donor-derived macrophages in the three analyzed muscles at 8 days, but not 3 hours, after adoptive transfer. Note, we found an increase of $\mathrm{BrdU}^{+}$ eGFP $^{-}$cells from 3 hours to 8 days, indicating that host along with donor macrophages are proliferating (Figure 3B). Together, these data suggested that after BM recruitment into the inflamed muscle, local macrophage proliferation leads to an accumulation of macrophages that is proportional to the extent of muscle disease.

\section{Dysf Deficiency in Muscle, Not Macrophages, Regulates Macrophage Proliferation in Dysferlinopathy}

To determine whether Dysf deficiency in macrophages altered macrophage proliferation in inflamed Dysf-deficient muscles, we compared the number of proliferative donor MacGreen:BLA/J and MacGreen:B6 macrophages after adoptive transfer into $\mathrm{BLA} / \mathrm{J}$ recipients at 10 to 12 months of age (Figure 3C). We detected similar numbers of eGFP ${ }^{+}$ macrophages in the inflamed Dysf-deficient muscle (psoas) of MacGreen:BLA/J and MacGreen:B6 BM cells at 3 hours and 5 and 8 days after adoptive transfer (Figure 3C). These data suggested that the Dysf-deficient muscle microenvironment, and not the absence of Dysf in macrophages, regulated the rate of macrophage proliferation and accumulation in dysferlinopathy. 
A

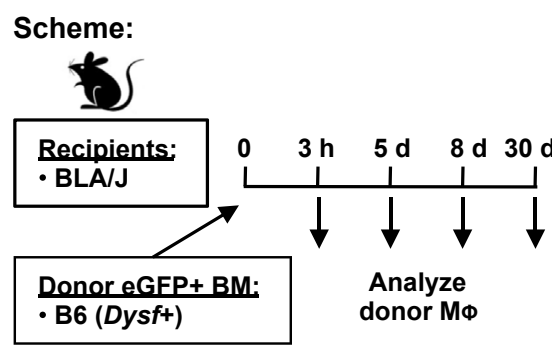

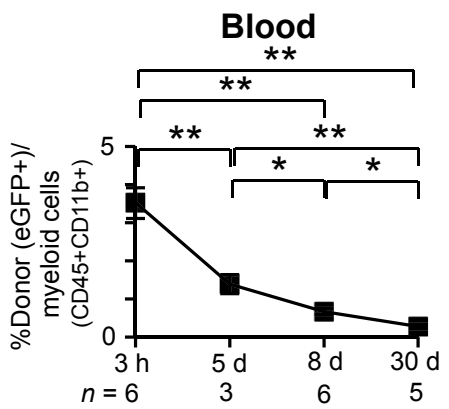

Muscles

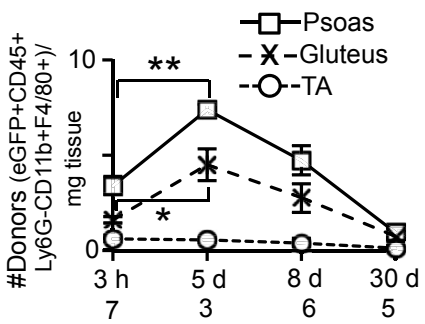

B
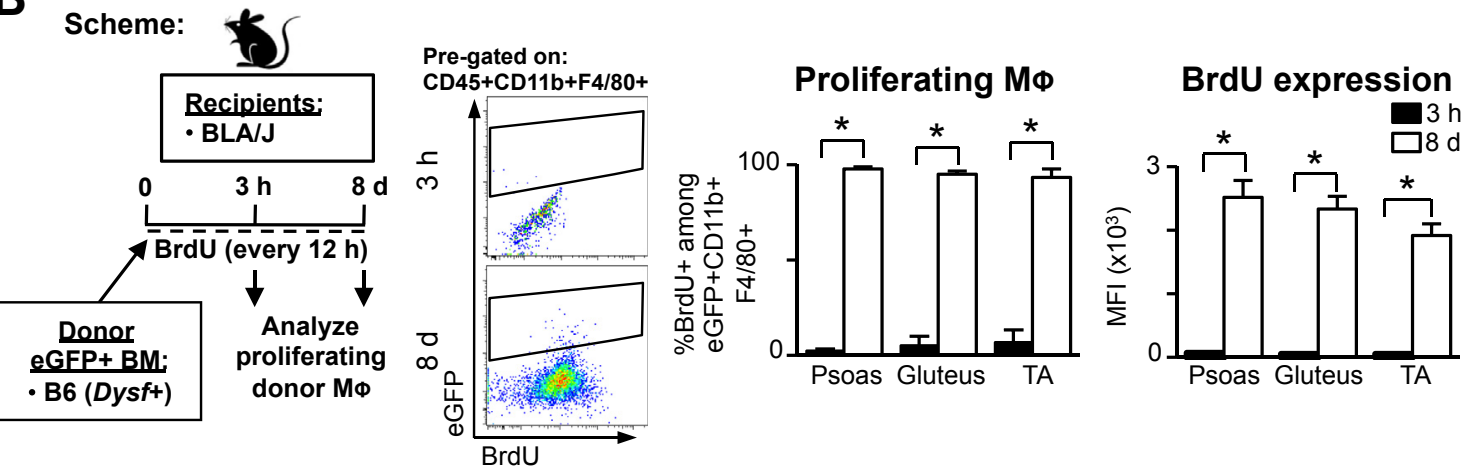

C
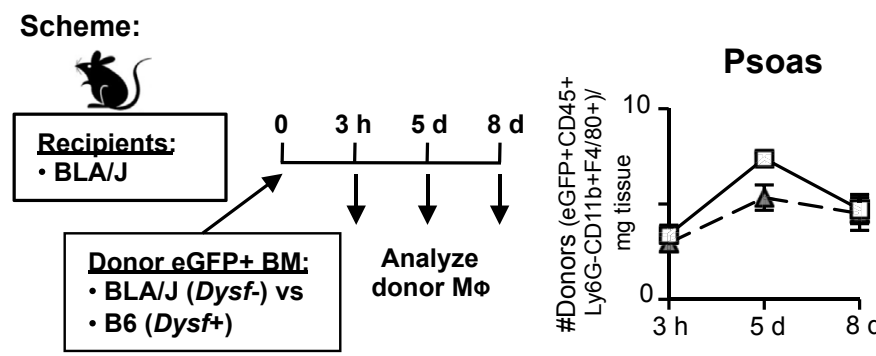

Gluteus

TA

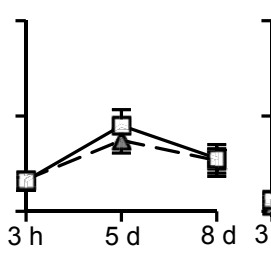

eGFP+ BM:

$-\triangle-$ Dysf-deficient

$\neg-D y s f$-intact

D

Scheme:

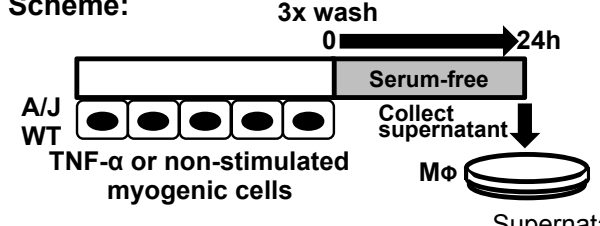

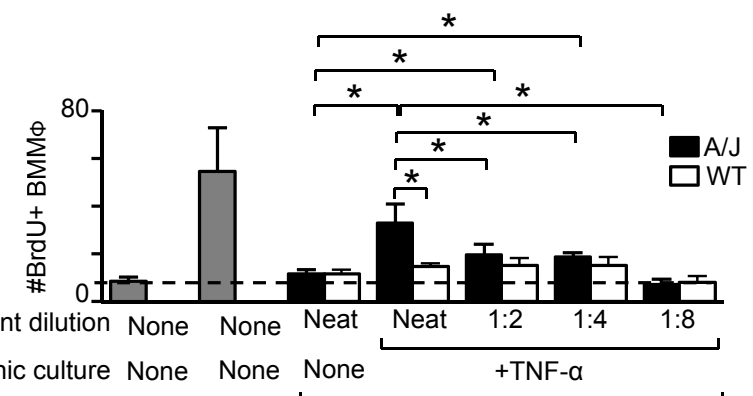

Myogenic culture None None None $\frac{+ \text { L929/FCS }}{\text { DMEM }}$

Supernatant

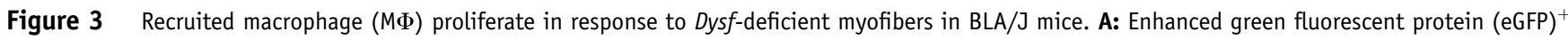
Dysf-intact bone marrow (BM) was adoptively transferred into BLA/J mice (10-12 months of age). Donor cell number in the blood and muscles was analyzed at 3 hours and 5, 8, and 30 days after adoptive transfer (AT). B: Bromodeoxyuridine (BrdU) incorporation by recruited MФs in muscles at 3 hours and 8 days after AT of MacGreen:B6 BM cells into BLA/J mice at 10 to 12 months of age. We administered $2 \mathrm{mg}$ of BrdU at the time of AT and then every 12 hours C: Comparison of donor eGFP ${ }^{+}$Dysf-deficient with intact donor $M \Phi$ number in three muscles. No significant difference was found between the two groups. D: $\mathrm{BrdU}^{+} \mathrm{BM}$ MФs stimulated with supernatant fluids from Dysf-deficient (A/J) and intact [wild-type (WT)] myogenic cells analyzed by flow cytometry. Dashed line (baseline) indicates BM $M \Phi$ cultured in serum-free Dulbecco's modified Eagle's medium (DMEM). Statistics analyzed with $U$-test. Data are expressed as means \pm SEM. $n=4$ (B); $n=3$ to 7 (C); $n=3$ to 4 (D). ${ }^{*} P<0.05,{ }^{*} P<0.01$. MFI, median fluorescence intensity; TA, tibialis anterior; TNF, tumor necrosis factor. 


\section{Dysf-Deficient Myogenic Cells Promote Macrophage Proliferation in Vitro}

To test the hypothesis that Dysf-deficient myotubes directly promote macrophage proliferation, we used an in vitro approach (Figure 3D). Therefore, we differentiated myotubes from Dysf-deficient (A/J) and Dysf-intact (WT) myoblasts (single to triple nucleated myocytes; referred to as myogenic cells). Then, we analyzed macrophage proliferation after exposure to Dysf-deficient and -intact (TNF- $\alpha$ stimulated) myogenic cell-conditioned media. Supernatant fluid (neat) derived from Dysf-deficient, but not Dysf-intact myogenic cells, induced macrophage proliferation (Figure 3D). Note, macrophages stimulated with L929 and fetal calf serum and media alone (DMEM) served as positive and negative controls, respectively. Taken together, these data suggested that Dysf-deficient muscle directly promotes intramuscle macrophage proliferation.

\section{Intramuscle Proliferating Macrophages Display a Cyto-Destructive Phenotype in Dysferlinopathy}

Because macrophage-rich Dysf-deficient muscles progressively deteriorated with time, we hypothesized that the accumulating macrophages are skewed toward a cytodestructive phenotype. To test this hypothesis, we probed for cyto-destructive (M1) and tissue-reparative phenotypes (M2) during advancing stages of dysferlinopathy in BLA/J mice: before (1.5 months of age), mild ( 8 months of age), and advanced (14 months of age). We probed for the

\section{A Total $M \Phi(C D 11 b+F 4 / 80+)$}

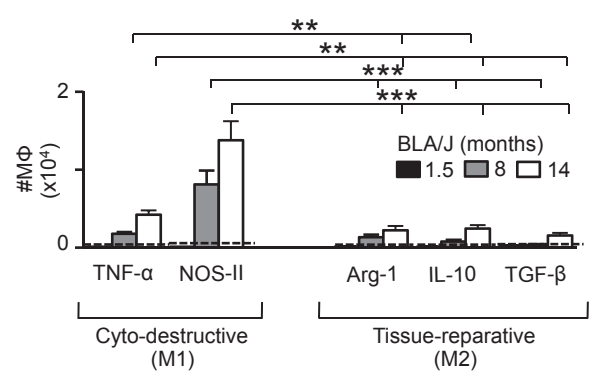

B Proliferating $M \Phi(B r d U+C D 11 b+F 4 / 80+)$
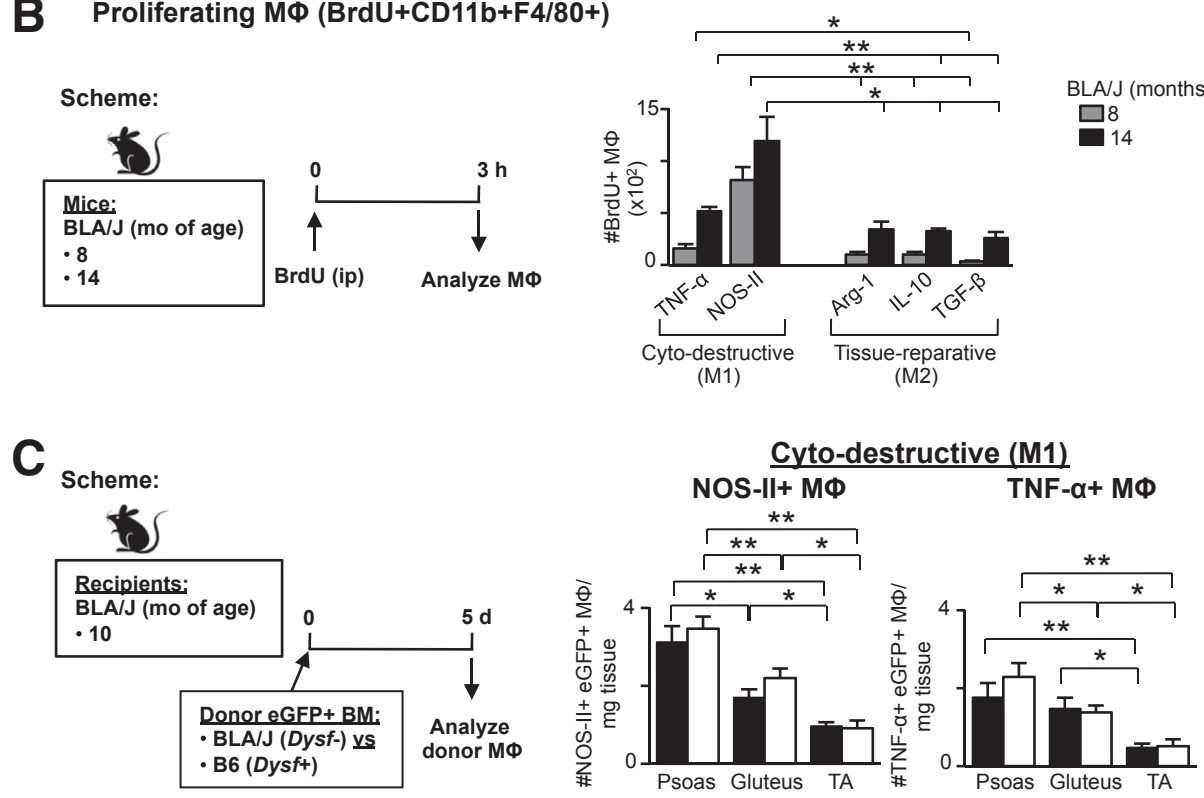

Tissue-reparative (M2)
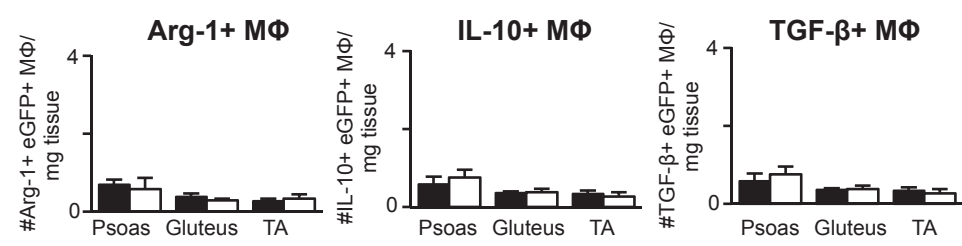

\section{M1:M2 ratio}

$\square_{\mathrm{B} 6}^{\mathrm{BLA} / \mathrm{J}}$ (8 months)

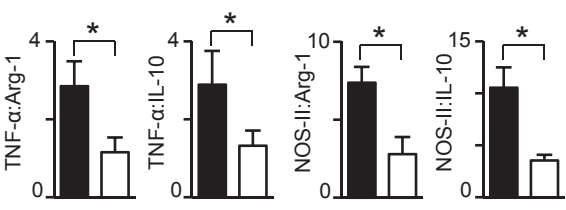

Figure 4 Proliferating macrophages (M $\Phi$ ) in BLA/J muscles express cyto-destructive mediators, rather than tissue-reparative cytokines. A: MФs isolated from gluteus muscles of BLA/J mice (8 and 14 months of age) stained for proinflammatory and tissuereparative cytokines evaluated by flow cytometry. Graphs represent MФs expressing classically activated (M1) and alternatively activated (M2) markers in gluteus muscles of BLA/J mice during advancing age. Dashed lines indicate $M \Phi s$ in gluteus muscles of $B 6$ mice (8 months of age). B: Analysis of proliferating $\mathrm{M} \Phi \mathrm{s}\left(\mathrm{BrdU}^{+}\right)$in $\mathrm{BLA} / \mathrm{J}$ mice (3 hours) after injecting BrdU. C: eGFP ${ }^{+}$Dysfdeficient and -intact bone marrow (BM) $\left(1 \times 10^{8}\right)$ were adoptively transferred into BLA $/ \mathrm{J}$ recipients (10 months of age). Polarization of donor Mథs was analyzed (5 days later) in the psoas, gluteus, and tibialis anterior (TA) muscles using flow cytometry. Statistics analyzed with U-test. Data are expressed as means \pm SEM. $n=5$ to 7 (A); $n=7$ (B); $n=6$ (C). ${ }^{*} P<0.05$, ${ }^{* *} P<0.01$, and $* * * P<0.001$. Arg-1, arginase-1; BrdU, bromodeoxyuridine; eGFP, enhanced green fluorescent protein; NOS-II, nitric oxide synthase type II; TGF, transforming growth factor; TNF, tumor necrosis factor. 
expression of functional molecules secreted from macrophages that mediate tissue injury (TNF- $\alpha,{ }^{7}$ NOS-II ${ }^{32}$ ) and repair (TGF- $\beta,{ }^{33}$ IL-10, ${ }^{32,34}$ and Arginase- $1^{34}$ ). We detected more cyto-destructive (TNF- $\alpha$ and NOS-II) compared with tissue-reparative (TGF- $\beta$, IL-10, and Arginase-1) markers with advancing disease (Figure 4A and Supplemental Figure S4B). By comparison, B6 intramuscle macrophages were far less skewed toward an M1 phenotype than age-matched BLA/J mice (Figure 4A). Note, although coexpression of macrophage markers added depth to phenotype analysis, our methods were restricted to single markers. Taken together, our data indicated that most macrophages in Dysf-deficient muscle express a cyto-destructive rather than tissue-reparative phenotype.

To quantify proliferating cyto-destructive and tissuereparative macrophage phenotypes during advancing dysferlinopathy, we injected BrdU (i.p.) and analyzed intramuscle macrophage expression of these phenotypes (after 3 hours) in mice at 8 and 14 months of age (Figure 4B). We determined that proliferating macrophages $\left(\mathrm{BrdU}^{+}\right)$predominantly expressed cyto-destructive compared with tissue-reparative macrophage markers in the gluteus muscle (Figure 4B). These data indicated that an expansion of M1 macrophages is associated with advancing dysferlinopathy.

To determine whether the absence of Dysf in macrophages promoted skewing toward a cyto-destructive macrophage phenotype, we compared the magnitude of cyto-destructive with tissue-reparative macrophages in adoptively transferred BM cells from MacGreen:BLA/J and MacGreen:B6 mice. Moreover, we quantified cyto-destructive and tissue-reparative donor $\mathrm{eFFP}^{+}$macrophages in muscle groups (psoas, gluteus, TA) with varying degrees of disease (Figure 4C). We detected similar numbers of $\mathrm{eGFP}^{+}$cyto-destructive and tissuereparative macrophages in the inflamed muscle after adoptive transfer. Thus, macrophage Dysf expression did not alter cyto-destructive or tissue-reparative macrophage accumulation in Dysf-deficient muscle.

\section{Dysf-Deficient Myogenic Cells Promote Cyto-Destructive Macrophage Phenotypes in Vitro}

Cytokine expression is intrinsically elevated in Dysfdeficient myofibers. ${ }^{23,29}$ Therefore, we hypothesized that Dysf-deficient myogenic cells express molecules that skew macrophages toward a cyto-destructive phenotype. To test this hypothesis, we stimulated IFN- $\gamma-$ primed B6 macrophages with conditioned media from A/J and WT myogenic cultures at day 5 of differentiation (Figure 5A). Dysfdeficient, but not Dysf-intact, conditioned media promoted the expression of cyto-destructive macrophage markers (TNF- $\alpha$ and NOS-II), similar to that induced by LPS stimulation (Figure 5A). By comparison, conditioned media from WT cultures increased macrophage tissue-reparative phenotype (TGF- $\beta$ ). Together, these data indicated that Dysf-deficient myogenic cultures promote a cyto-destructive macrophage phenotype.
Cyto-Destructive Macrophages Promote Apoptosis/ Necrosis in Dysf-Deficient Myogenic Cells in Vitro

We identified more proliferating cyto-destructive compared with tissue-reparative macrophages accumulating in Dysfdeficient inflamed muscle. Moreover, cyto-destructive macrophages progressively accumulated with advancing dysferlinopathy. Notably, most cyto-destructive macrophages in BLA/J muscle were adjacent to necrotic myofibers (Supplemental Figure S2C). Thus, we hypothesized that proliferating cyto-destructive macrophages promoted myofiber damage and thereby contributed to advancing dysferlinopathy. To determine whether cyto-destructive macrophage induced muscle death (apoptosis, necrosis), we compared macrophage-mediated apoptosis (Annexin V) and necrosis (propidium iodide) in Dysf-deficient and -intact myogenic cultures. Dysf-deficient and -intact myogenic cultures were stimulated with M1 (TNF- $\alpha$, NOS-II expressing) macrophage supernatant fluid (24 hours) (Figure 5B). M1 macrophages induced apoptosis and necrosis in Dysf-deficient and -intact myogenic cultures (Figure 5B). Importantly, Dysf-deficient myogenic cultures were more susceptible to macrophagemediated apoptosis and necrosis than Dysf-intact myogenic cell cultures (Figure 5B). Taken together, our findings indicated that Dysf-deficient compared with Dysf-intact myogenic cells were more vulnerable to M1 macrophage-mediated muscle destruction, at least in vitro.

From our findings, we propose that the following are key steps leading to dysferlinopathy (Figure 6): i) intrinsic defective muscle repair (the Dysf-deficient muscle microenvironment), ii) macrophage recruitment from BM, iii) intramuscle macrophage proliferation, iv) intramuscle macrophage polarization toward a M1 cyto-destructive phenotype, and v) macrophage-mediated muscle apoptosis/necrosis.

\section{Discussion}

We tested the hypothesis that Dysf-deficient muscle promotes recruitment, proliferation, and skewing of macrophages toward a cyto-destructive phenotype in dysferlinopathy. With the use of in vivo strategies, most notably genetic fate mapping, coupled with in vitro macrophage and myogenic cell interactions, we report the following novel findings: i) the Dysf-deficient muscle microenvironment recruits macrophage, skews these myeloid cells toward an M1 macrophage cyto-destructive, not an M2 macrophage tissue-reparative, phenotype, and fosters proliferation of cyto-destructive macrophage; ii) intramuscle macrophage recruitment and proliferation increases with advancing dysferlinopathy; iii) Dysf-deficient compared with Dysf-intact myogenic cultures are more vulnerable to M1 macrophage-mediated muscle destruction (apoptosis/necrosis); and iv) the absence of Dysf in muscle, but not in macrophages, mediates macrophage recruitment into the inflamed muscle, promotes macrophage proliferation, likely leading to destruction. Taken together, 


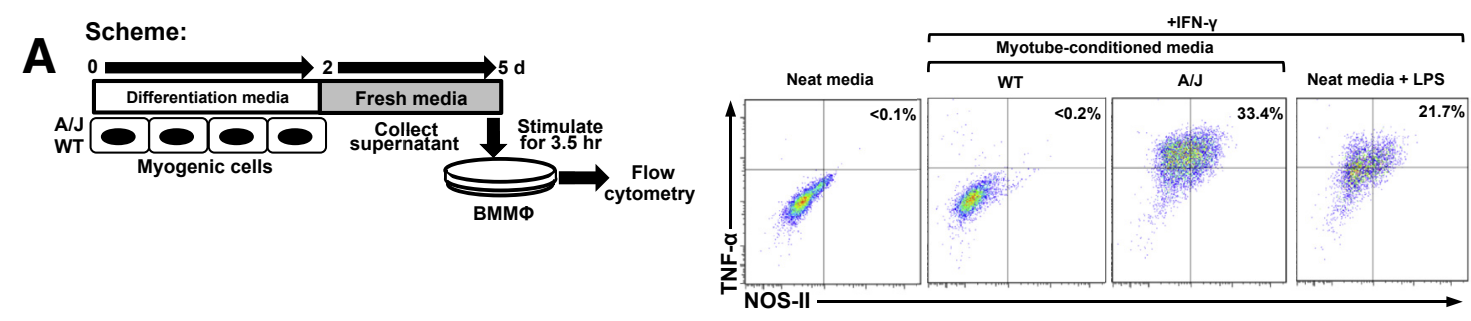

\section{Cyto-destructive $M \Phi$}
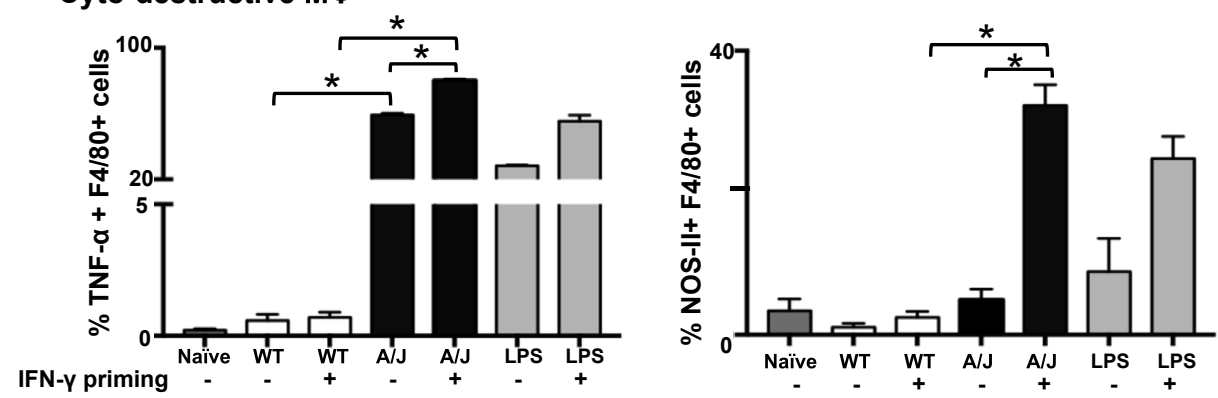

\section{Tissue-reparative $M \Phi$}
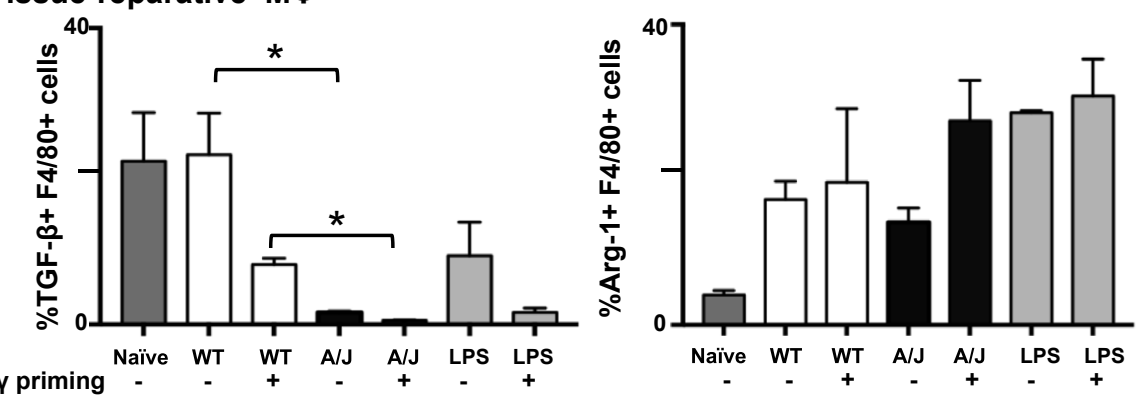

B
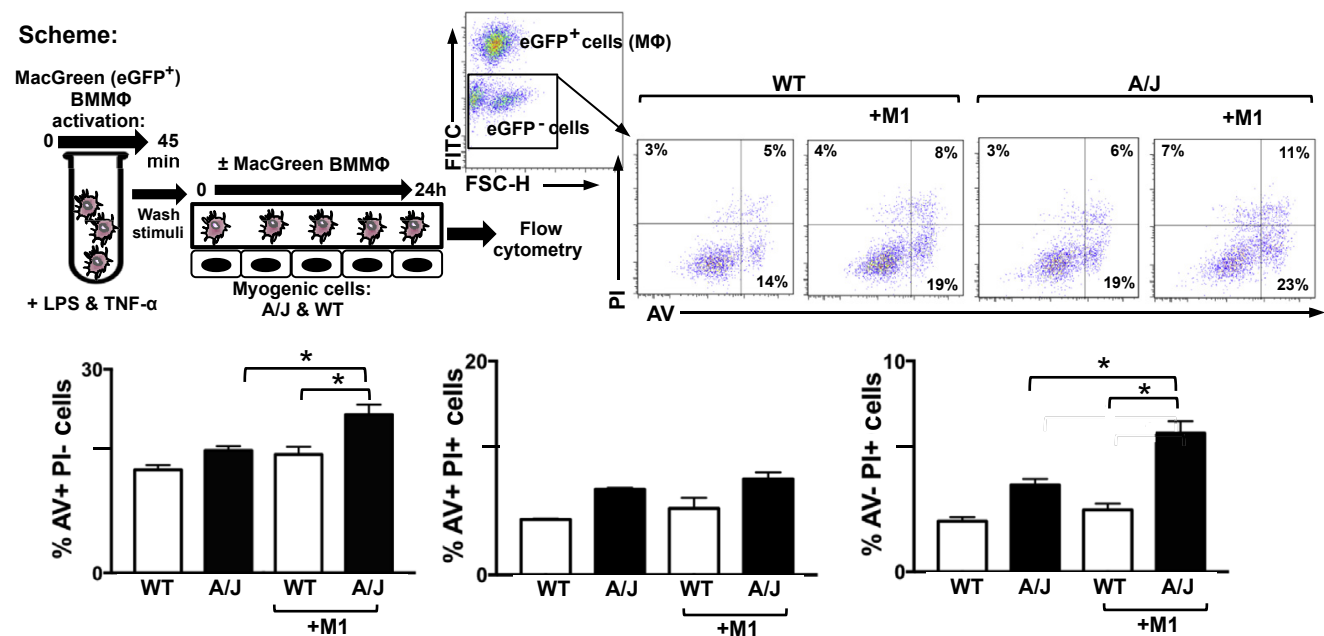

Figure 5 Dysf-deficient myogenic cells promote classically activated (M1) macrophage (M $\Phi$ ) skewing which induces myotube apoptosis/necrosis in vitro. A: MФs primed with interferon (IFN)- $\gamma$ and subsequently stimulated with myogenic cell-conditioned media. Cells were harvested for intracellular staining using flow cytometry. Representative fluorescence-activated cell sorting (FACS) plots of M1 and alternatively activated (M2) M $\Phi$ skewing. Graphs are M $\Phi$ skewing in response to myogenic cell-conditioned media. B: Dysf-deficient and wild-type (WT) myoblasts induced to differentiate at approximately $70 \%$ confluence. MacGreen MФs suspended in myotube differentiation media were added to myogenic cultures after stimulation. After 24 hours of co-culture, cells were harvested and stained with Annexin V (AV) and propidium iodide (PI). Flow cytometry was performed on myogenic cells identified as enhanced green fluorescent protein (eGFP) $)^{-}$cells. Graphs are early apoptotic $\left(\mathrm{AV}^{+} \mathrm{PI}^{-}\right)$, apoptotic/necrotic $\left(\mathrm{AV}^{+} \mathrm{PI}^{+}\right)$, and necrotic $\left(\mathrm{AV}^{-} \mathrm{PI}^{+}\right)$cells. Statistics analyzed with U-test. Data are expressed as means \pm SEM. $n=3(\mathbf{A}) ; n=3$ to 4 (B). ${ }^{*} P<0.05$. Arg-1, arginase-1; BM bone marrow; FITC, fluorescein isothiocyanate; FSC, forward scatter; LPS, lipopolysaccharide; NOS-II, nitric oxide synthase type II; TGF, transforming growth factor; TNF, tumor necrosis factor. 


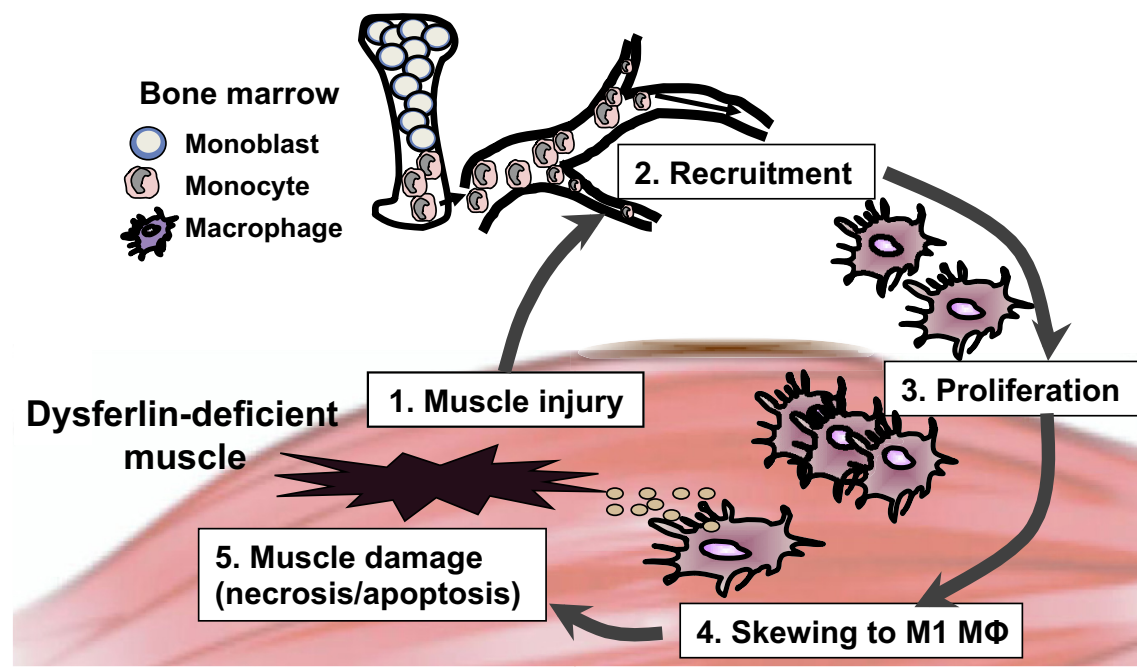

Figure 6 Macrophage (M $\Phi$ )-mediated muscle destruction during dysferlinopathy. We propose key steps leading to dysferlinopathy: 1) intrinsic defective muscle repair, the Dysf-deficient muscle microenvironment, 2) recruits $M \Phi$ from bone marrow, 3) fosters $M \Phi$ proliferation, 4) polarizes $M \Phi$ toward an classically activated (M1) cytodestructive phenotype which in turn, and 5) releases mediators that induce apoptosis/necrosis and thereby destroy muscle.

although dysferlinopathy is most likely intrinsically initiated in muscle, our data suggest that the influx and expansion of cyto-destructive macrophage phenotypes may contribute to advancing disease.

Macrophage accumulation in Dysf-deficient muscle is a hallmark for dysferlinopathy. However, even in a muscle destined for destruction, there are multiple reasons for intramuscle macrophage accumulation. As in acute injury, intramuscle macrophages may be healers, but repeated, persistent muscle insults may override macrophagemediated repair and thereby lead to loss of function. We have ruled out this possibility. We report that the Dysfdeficient inflamed muscle microenvironment recruits macrophages that are polarized toward a cyto-destructive phenotype and expand locally. These events escalate with age in BLA/J mice and are thereby likely to contribute to unrelenting muscle damage, suggesting that inflamed Dysfdeficient muscle generates molecules, such as cytokines and damage-associated molecular patterns, which directly or indirectly polarize and sustain a cyto-destructive macrophage phenotype. One plausible candidate is IL-1 $\beta$. For example, stimulated Dysf-deficient compared with Dysfintact primary myotubes secrete IL- $1 \beta,{ }^{23,24,29}$ which can induce macrophages to express TNF- $\alpha,{ }^{35}$ and in turn lead to muscle wasting. ${ }^{36}$ IFN- $\gamma$ is another cytokine likely expressed in Dysf-deficient myotubes ${ }^{24}$ and injured muscles, ${ }^{37}$ which is capable of polarizing macrophages toward an M1 phenotype. ${ }^{38}$ There are numerous other inflammatory molecules that are expressed in Dysf-deficient human mus$\mathrm{cle}^{39}$ that may promote cytokine-rich inflammation and, in turn, macrophage skewing in dysferlinopathy. For example, TNF- $\alpha$ may be a useful therapeutic target in dysferlinopathy. TNF- $\alpha$ inhibition attenuates muscle disease in dystrophin deficiency (Duchenne's muscular dystrophy). ${ }^{40,41}$ Further, in mucopolysaccharidoses, an inherited lysosomal storage disease, TNF- $\alpha$ inhibition attenuates cellular apoptosis and disease characteristics. ${ }^{42,43}$ Because Dysfdeficient myoblasts display impaired lysosome trafficking, ${ }^{44}$ this further supports the therapeutic utility of inhibiting TNF- $\alpha$ in dysferlinopathy. An ideal therapeutic would convert destroyer to healers, a difficult task to even begin without knowing the precise cocktail of cytokines in the Dysf-deficient muscles that polarize macrophages toward cyto-destroyers.

Sterile inflammation originates intrinsically within Dysfdeficient muscles, plausibly triggered by impaired membrane sealing in response to muscle damage. ${ }^{3,15,45}$ Faulty muscle repair results in continuous macrophage recruitment into in Dysf-defective injured muscles. With the use of genetic fate mapping to track macrophages, we now report that macrophage recruitment escalates with advancing age in dysferlinopathy in a muscle-specific pattern. Chemokines, such as monocyte chemoattractant protein 1 , known to draw monocytes into tissues, up-regulated in Dysf-deficient hosts, ${ }^{24}$ are likely candidates responsible for recruiting macrophages into inflamed muscles. ${ }^{46}$ For example, monocyte chemoattractant protein 1 and CCR2 are upregulated in Dysf-deficient muscles, and targeting CCR2 results in improved symptoms and function. ${ }^{24,47}$ Moreover, mobilization of macrophages is impaired from BM to blood and blood to injured muscle in CCR2 knockout mice. ${ }^{48} \mathrm{We}$ show that WT macrophages are recruited into the Dysfdeficient microenvironment. These data suggest that Dysfdeficient muscle is responsible for drawing macrophages into the injured muscle before skewing these myeloid cells toward a cyto-destructive phenotype.

Because macrophage express Dysf, a central issue has been whether the absence of Dysf in macrophages, in addition to muscle, regulates macrophage action in the pathogenesis of dysferlinopathy. With the use of genetic fate mapping to track macrophages with and without Dysf expression, we show that the Dysf-deficient muscle, independent of macrophage Dysf expression, recruits and fosters intramuscle macrophage proliferation. Consistent with this finding, Dysf-intact BM transplanted into Dysf-deficient mice does not improve muscle function. ${ }^{14}$ Within the 
context of gene therapy and based on our findings, restoration of Dysf expression in muscle, not macrophages, is likely necessary for therapeutic benefit.

There are several explanations as to why Dysf-deficient compared with Dysf-intact muscle is more vulnerable to macrophage-mediated apoptosis/necrosis. Dysf is a key protein in muscle membrane repair and vesicle trafficking ${ }^{49}$; thus, the absence of Dysf increases muscle susceptibility to injury. More specifically, intrinsic impairments in $\mathrm{Ca}^{2+}$ regulation likely predispose damage in the context of both contraction and inflammation-induced muscle injury. For example, NOS-II disrupts $\mathrm{Ca}^{2+}$ signaling to promote muscle damage in Dysf-deficient mice. Moreover, similar to dystrophin-deficient muscle, in the absence of Dysf contraction-induced myofiber $\mathrm{Ca}^{2+}$ influx likely leads to proteasome activation and protein degradation. ${ }^{50-52}$ Given the vulnerability of Dysf-deficient muscle to macrophagemediated apoptosis/necrosis, we suggest that a reduction in cyto-destructive macrophages within muscle is central to suppressing muscular dystrophy. However, because these observations were made in vitro, further in vivo experiments are required to validate this hypothesis. In addition, our myogenic cultures contained both myocytes and larger multinucleated myotubes. Use of ex vivo single-fiber cultures may help elucidate whether macrophages directly induce myofiber destruction in dysferlinopathy. Further, we did not evaluate the effects of Dysf-deficient macrophages on myofiber apoptosis/necrosis because of technical limitations.

Taken together, we report an expansion of cyto-destructive macrophages in muscle that are associated with promoting dysferlinopathy. Because proliferating cyto-destructive macrophages are prominent in inflamed Dysf-deficient muscles, suppressing intramuscle macrophage recruitment, proliferation of cyto-destructive macrophage, and/or converting cytodestructive to tissue reparative macrophages are promising therapeutic approaches for suppressing dysferlinopathy.

\section{Acknowledgments}

We thank David Fernandez and Yukihiro Wada for technical assistance, Hillarie Windish and Douglas Albrecht for helpful discussion, and Dr. Terence Partridge and James Novak (Children's National Medical Center) for providing H2K myogenic cells.

\section{Supplemental Data}

Supplemental material for this article can be found at http://dx.doi.org/10.1016/j.ajpath.2017.02.011.

\section{References}

1. Liu J, Aoki M, Illa I, Wu C, Fardeau M, Angelini C, Serrano C, Urtizberea JA, Hentati F, Hamida MB, Bohlega S, Culper EJ,
Amato AA, Bossie K, Oeltjen J, Bejaoui K, McKenna-Yasek D, Hosler BA, Schurr E, Arahata K, de Jong PJ, Brown RH Jr: Dysferlin, a novel skeletal muscle gene, is mutated in Miyoshi myopathy and limb girdle muscular dystrophy. Nat Genet 1998, $20: 31-36$

2. Bashir R, Britton S, Strachan T, Keers S, Vafiadaki E, Lako M, Richard I, Marchand S, Bourg N, Argov Z, Sadeh M, Mahjneh I, Marconi G, Passos-Bueno MR, Moreira Ede S, Zatz M, Beckmann JS, Bushby K: A gene related to Caenorhabditis elegans spermatogenesis factor fer-1 is mutated in limb-girdle muscular dystrophy type 2B. Nat Genet 1998, 20:37-42

3. Bansal D, Miyake K, Vogel SS, Groh S, Chen CC, Williamson R, McNeil PL, Campbell KP: Defective membrane repair in dysferlindeficient muscular dystrophy. Nature 2003, 423:168-172

4. Gallardo E, Rojas-Garcia R, de Luna N, Pou A, Brown RH Jr, Illa I: Inflammation in dysferlin myopathy: immunohistochemical characterization of 13 patients. Neurology 2001, 57:2136-2138

5. Martinez FO, Sica A, Mantovani A, Locati M: Macrophage activation and polarization. Front Biosci 2008, 13:453-461

6. Murray PJ, Wynn TA: Obstacles and opportunities for understanding macrophage polarization. J Leukoc Biol 2011, 89:557-563

7. Arnold L, Henry A, Poron F, Baba-Amer Y, van Rooijen N, Plonquet A, Gherardi RK, Chazaud B: Inflammatory monocytes recruited after skeletal muscle injury switch into antiinflammatory macrophages to support myogenesis. J Exp Med 2007, 204: 1057-1069

8. Fadok VA, Bratton DL, Guthrie L, Henson PM: Differential effects of apoptotic versus lysed cells on macrophage production of cytokines: role of proteases. J Immunol 2001, 166:6847-6854

9. Huynh ML, Fadok VA, Henson PM: Phosphatidylserine-dependent ingestion of apoptotic cells promotes TGF-betal secretion and the resolution of inflammation. J Clin Invest 2002, 109:41-50

10. Xu W, Roos A, Schlagwein N, Woltman AM, Daha MR, van Kooten C: IL-10-producing macrophages preferentially clear early apoptotic cells. Blood 2006, 107:4930-4937

11. Savill J, Fadok V: Corpse clearance defines the meaning of cell death. Nature 2000, 407:784-788

12. Summan M, Warren GL, Mercer RR, Chapman R, Hulderman T, Van Rooijen N, Simeonova PP: Macrophages and skeletal muscle regeneration: a clodronate-containing liposome depletion study. Am J Physiol Regul Integr Comp Physiol 2006, 290:R1488-R1495

13. Roche JA, Tulapurkar ME, Mueller AL, van Rooijen N, Hasday JD, Lovering RM, Bloch RJ: Myofiber damage precedes macrophage infiltration after in vivo Injury in dysferlin-deficient $\mathrm{A} / \mathrm{J}$ mouse skeletal muscle. Am J Pathol 2015, 185:1686-1698

14. Flix B, Suarez-Calvet X, Diaz-Manera J, Santos-Nogueira E, Mancuso R, Barquinero J, Navas M, Navarro X, Illa I, Gallardo E: Bone marrow transplantation in dysferlin-deficient mice results in a mild functional improvement. Stem Cells Dev 2013, 22:2885-2894

15. Millay DP, Maillet M, Roche JA, Sargent MA, McNally EM, Bloch RJ, Molkentin JD: Genetic manipulation of dysferlin expression in skeletal muscle: novel insights into muscular dystrophy. Am J Pathol 2009, 175:1817-1823

16. Vafiadaki E, Reis A, Keers S, Harrison R, Anderson LV, Raffelsberger T, Ivanova S, Hoger H, Bittner RE, Bushby K, Bashir R: Cloning of the mouse dysferlin gene and genomic characterization of the SJL-Dysf mutation. Neuroreport 2001, 12:625-629

17. Hornsey MA, Laval SH, Barresi R, Lochmuller H, Bushby K: Muscular dystrophy in dysferlin-deficient mouse models. Neuromuscul Disord 2013, 23:377-387

18. Menke J, Iwata Y, Rabacal WA, Basu R, Yeung YG, Humphreys BD, Wada T, Schwarting A, Stanley ER, Kelley VR: CSF-1 signals directly to renal tubular epithelial cells to mediate repair in mice. J Clin Invest 2009, 119:2330-2342

19. Jang MH, Herber DM, Jiang X, Nandi S, Dai XM, Zeller G, Stanley ER, Kelley VR: Distinct in vivo roles of colony-stimulating factor-1 isoforms in renal inflammation. J Immunol 2006, 177:4055-4063 
20. Committee for the Update of the Guide for the Care and Use of Laboratory AnimalsNational Research Council: Guide for the Care and Use of Laboratory Animals: Eighth Edition. Washington, DC, National Academies Press, 2011

21. Baek JH, Zeng R, Weinmann-Menke J, Valerius MT, Wada Y, Ajay AK, Colonna M, Kelley VR: IL-34 mediates acute kidney injury and worsens subsequent chronic kidney disease. J Clin Invest 2015, 125:3198-3214

22. Menke J, Lucas JA, Zeller GC, Keir ME, Huang XR, Tsuboi N, Mayadas TN, Lan HY, Sharpe AH, Kelley VR: Programmed death 1 ligand (PD-L) 1 and PD-L2 limit autoimmune kidney disease: distinct roles. J Immunol 2007, 179:7466-7477

23. Cohen TV, Cohen JE, Partridge TA: Myogenesis in dysferlindeficient myoblasts is inhibited by an intrinsic inflammatory response. Neuromuscul Disord 2012, 22:648-658

24. Cohen TV, Many GM, Fleming BD, Gnocchi VF, Ghimbovschi S, Mosser DM, Hoffman EP, Partridge TA: Upregulated IL-1beta in dysferlin-deficient muscle attenuates regeneration by blunting the response to pro-inflammatory macrophages. Skelet Muscle 2015, 5:24

25. Lostal W, Bartoli M, Bourg N, Roudaut C, Bentaib A, Miyake K, Guerchet N, Fougerousse F, McNeil P, Richard I: Efficient recovery of dysferlin deficiency by dual adeno-associated vector-mediated gene transfer. Hum Mol Genet 2010, 19:1897-1907

26. Bushby KM: Making sense of the limb-girdle muscular dystrophies. Brain 1999, 122(Pt 8):1403-1420

27. Sasmono RT, Oceandy D, Pollard JW, Tong W, Pavli P, Wainwright BJ, Ostrowski MC, Himes SR, Hume DA: A macrophage colony-stimulating factor receptor-green fluorescent protein transgene is expressed throughout the mononuclear phagocyte system of the mouse. Blood 2003, 101:1155-1163

28. Nagaraju K, Rawat R, Veszelovszky E, Thapliyal R, Kesari A, Sparks S, Raben N, Plotz P, Hoffman EP: Dysferlin deficiency enhances monocyte phagocytosis: a model for the inflammatory onset of limb-girdle muscular dystrophy 2B. Am J Pathol 2008, 172:774-785

29. Rawat R, Cohen TV, Ampong B, Francia D, Henriques-Pons A, Hoffman EP, Nagaraju K: Inflammasome up-regulation and activation in dysferlin-deficient skeletal muscle. Am J Pathol 2010, 176: $2891-2900$

30. Hashimoto D, Chow A, Noizat C, Teo P, Beasley MB, Leboeuf M, Becker CD, See P, Price J, Lucas D, Greter M, Mortha A, Boyer SW, Forsberg EC, Tanaka M, van Rooijen N, Garcia-Sastre A, Stanley ER, Ginhoux F, Frenette PS, Merad M: Tissue-resident macrophages self-maintain locally throughout adult life with minimal contribution from circulating monocytes. Immunity 2013, 38: 792-804

31. Gordon S: Alternative activation of macrophages. Nat Rev Immunol 2003, 3:23-35

32. Villalta SA, Nguyen HX, Deng B, Gotoh T, Tidball JG: Shifts in macrophage phenotypes and macrophage competition for arginine metabolism affect the severity of muscle pathology in muscular dystrophy. Hum Mol Genet 2009, 18:482-496

33. Milner DJ, Cameron JA: Muscle repair and regeneration: stem cells, scaffolds, and the contributions of skeletal muscle to amphibian limb regeneration. Curr Top Microbiol Immunol 2013, 367:133-159

34. Deng B, Wehling-Henricks M, Villalta SA, Wang Y, Tidball JG: IL10 triggers changes in macrophage phenotype that promote muscle growth and regeneration. J Immunol 2012, 189:3669-3680

35. Jayaraman P, Sada-Ovalle I, Nishimura T, Anderson AC, Kuchroo VK, Remold HG, Behar SM: IL-1beta promotes antimicrobial immunity in macrophages by regulating TNFR signaling and caspase-3 activation. J Immunol 2013, 190:4196-4204

36. Reid MB, Li YP: Tumor necrosis factor-alpha and muscle wasting: a cellular perspective. Respir Res 2001, 2:269-272
37. Cheng M, Nguyen MH, Fantuzzi G, Koh TJ: Endogenous interferongamma is required for efficient skeletal muscle regeneration. Am J Physiol Cell Physiol 2008, 294:C1183-C1191

38. Nathan CF, Murray HW, Wiebe ME, Rubin BY: Identification of interferon-gamma as the lymphokine that activates human macrophage oxidative metabolism and antimicrobial activity. J Exp Med 1983, 158:670-689

39. Kesari A, Fukuda M, Knoblach S, Bashir R, Nader GA, Rao D, Nagaraju K, Hoffman EP: Dysferlin deficiency shows compensatory induction of Rab27A/Slp2a that may contribute to inflammatory onset. Am J Pathol 2008, 173:1476-1487

40. Ermolova NV, Martinez L, Vetrone SA, Jordan MC, Roos KP, Sweeney HL, Spencer MJ: Long-term administration of the TNF blocking drug Remicade (cV1q) to mdx mice reduces skeletal and cardiac muscle fibrosis, but negatively impacts cardiac function. Neuromuscul Disord 2014, 24:583-595

41. Radley HG, Davies MJ, Grounds MD: Reduced muscle necrosis and long-term benefits in dystrophic mdx mice after cV1q (blockade of TNF) treatment. Neuromuscul Disord 2008, 18:227-238

42. Eliyahu E, Wolfson T, Ge Y, Jepsen KJ, Schuchman EH, Simonaro CM: Anti-TNF-alpha therapy enhances the effects of enzyme replacement therapy in rats with mucopolysaccharidosis type VI. PLoS One 2011, 6:e22447

43. Simonaro CM, Ge Y, Eliyahu E, He X, Jepsen KJ, Schuchman EH: Involvement of the Toll-like receptor 4 pathway and use of TNFalpha antagonists for treatment of the mucopolysaccharidoses. Proc Natl Acad Sci U S A 2010, 107:222-227

44. Defour A, Van der Meulen JH, Bhat R, Bigot A, Bashir R, Nagaraju K, Jaiswal JK: Dysferlin regulates cell membrane repair by facilitating injury-triggered acid sphingomyelinase secretion. Cell Death Dis 2014, 5:e1306

45. Demonbreun AR, Quattrocelli M, Barefield DY, Allen MV Swanson KE, McNally EM: An actin-dependent annexin complex mediates plasma membrane repair in muscle. J Cell Biol 2016, 213: 705-718

46. Miyatake S, Bilan PJ, Pillon NJ, Klip A: Contracting C2C12 myotubes release CCL2 in an NF-kappaB-dependent manner to induce monocyte chemoattraction. Am J Physiol Endocrinol Metab 2016, 310:E160-E170

47. Mojumdar K, Liang F, Giordano C, Lemaire C, Danialou G, Okazaki T, Bourdon J, Rafei M, Galipeau J, Divangahi M, Petrof BJ: Inflammatory monocytes promote progression of Duchenne muscular dystrophy and can be therapeutically targeted via CCR2. EMBO Mol Med 2014, 6:1476-1492

48. Lu H, Huang D, Saederup N, Charo IF, Ransohoff RM, Zhou L: Macrophages recruited via CCR2 produce insulin-like growth factor-1 to repair acute skeletal muscle injury. FASEB J 2011, 25: $358-369$

49. Cardenas AM, Gonzalez-Jamett AM, Cea LA, Bevilacqua JA, Caviedes P: Dysferlin function in skeletal muscle: possible pathological mechanisms and therapeutical targets in dysferlinopathies. Exp Neurol 2016, 283:246-254

50. Kerr JP, Ziman AP, Mueller AL, Muriel JM, Kleinhans-Welte E, Gumerson JD, Vogel SS, Ward CW, Roche JA, Bloch RJ: Dysferlin stabilizes stress-induced $\mathrm{Ca} 2+$ signaling in the transverse tubule membrane. Proc Natl Acad Sci U S A 2013, 110: 20831-20836

51. Turner PR, Westwood T, Regen CM, Steinhardt RA: Increased protein degradation results from elevated free calcium levels found in muscle from mdx mice. Nature 1988, 335:735-738

52. Briguet A, Erb M, Courdier-Fruh I, Barzaghi P, Santos G, Herzner H, Lescop C, Siendt H, Henneboehle M, Weyermann P, Magyar JP, Dubach-Powell J, Metz G, Meier T: Effect of calpain and proteasome inhibition on $\mathrm{Ca} 2+-$ dependent proteolysis and muscle histopathology in the mdx mouse. FASEB J 2008, 22:4190-4200 